\title{
Research on Internationalization of Hotel Industry
}

\author{
Xiaosi Song \\ Department of Foreign Language \\ Harbin University of Commerce \\ Harbin, China
}

\begin{abstract}
This paper studies the most important trends nowadays seen in the international hotel industry, faced with the challenges and opportunities posed by the world economic environment. The research will examine the hotel industry activities and define its nature, illustrate the development of the internationalization of hotel industry and analyze the impact of technological advances and regulatory changes on the global production and delivery of the service.
\end{abstract}

Keywords - internationalization; hotel industry

\section{INTRODUCTION}

Today's business world has few geographic boundaries. Distance is continually overcome by technology, travel and the expansion of capitalism. Internationalization of the hotel industry has reached the top of corporate agendas and several hotel chains started to recognize that the international business environment will be basically different from that of the past.

For hotel industry, internationalization refers to a multinational strategy, which begins from hotel at one end whose strategy is multi domestic to those hotels at other end which are integrated transnational. An International Hotel Company is a company which has direct investment and other major forms of contractual agreements in more than one country.

\section{INTERNATIONALIZATION}

As recently as 30 years ago the international enterprise was a relatively rare phenomenon, and the term multinational was seldom heard. [5] Now, a lot of enterprises have exceeded the multinational stage and run as trans-national or international corporations. These labels reflect a main shift in the structure of the global market in terms of goods and services-a shift to a competitive structure which has profound influence for nearly all industries.

Internationalization have great effects on the SMEs. This is true for corporations running in destinations which having a extremely low level of integration, specialization, as well as level of monopoly and for those which don't cooperate at lowest on a small scale with the international players in worldwide tourism, which is more typical amongst new destinations. In traditional tourism fields, SMEs are not ready to work together with international players in worldwide tourism on a broad extent and to come into being internationally competitive destinations. The results for
SMEs are expense in market shares as well as increasing financial tension as changes for attracting new travelers by capitalizing on the international tendencies or the shift to 'post-modern' consumption frameworks are not realized [1].

\section{HOTEL INDUSTRY}

The hotel industry is a major sector of the tourism industry, which, in turn, is one of the most rapidly expanding fields in the service industry. In accordance with the world travel and tourism council (WTTC), travel as well as tourism has become the principal economic provider to the world or national economies from the aspects of value-added, capital investment, employment, output and the contribution of tax revenue.

Hotel industry is of essential significance to the development of travel and tourism, for the reason that it could meet the accommodation requirements of the 'away from home market'. The development and situation of the current hotel industry has been shaped by a series of economic characteristics that could be summarized as follows:

- Hotel industry is exceedingly competitive. The severe competition is created by the outcome of overbuilding and excess capacity. Otherwise, the internationalization development has been increasing the amount of rivals in the hotel industry and, therefore, greatly forcing competition of markets.

- The personal service is emphasized in this labor intensive industry. In order to offer the customers quality service, employees have to be appropriately and well instructed, inspired and supervised. Despite the fact that it is costly, training is essential since a direct effect on whether the guest will return is had by the 'moments of truths' or the positive and negative image of the employee

- The hotel industry should be particularly sensitive to fluctuations in requirements. The product provided by hotels is hard to be preserved. The diminution of business travel and entertainment in a recessionary time naturally has unfavorable impacts on hotel accommodation, food and drink cost and, consequently, hotel profitability. On the whole, growing inflation leads to expenditure in the terms of energy, labor, as well as construction to increase and profit margins to wear down, in particular when the 
hotel cannot lift room rates proportionately because of current market circumstances. By contraries, a stable and expanding economy are more likely to positively impact hotel performance.

\section{HISTORY OF INTERNATIONALIZATION OF THE HOTEL INDUSTRY}

The international hotel industry has a long history of development. It begins in the post war period at what time quite a few of current main multinational hotel chains were set up. As a result, the 1940s and 1950s are important decades in the internationalization of hotel operations. After World War II, lack of quality accommodations is caused by the development of international air transportation which transporting larger numbers of passengers in many locations. In 1946, Pan American Airways' created Inter-Continental Hotels to provide its passengers and crews with modern accommodation in Latin America [4] That is the beginning of the international hotel chains.

From post-WWII to the end of 1970s, Europe and North America subjected the worldwide hotel industry. In 1978, eight of the top ten global hotel chains were US-owned [4] Hotels associated with US-based multinational enterprises are about 55 percent of all the multinational- associated hotels and are 60 percent of the rooms. Moreover, hotels associated with United Kingdom-based as well as Francebased multinational enterprises accounted for 30 percent of all multinational-associated hotels and for 25 percent of the rooms[3].

The international accommodation capacity rose from 9 to 16.5 million beds from 1980 to 1998 . The largest rise occurred in the European countries, accounting for 39 percent, followed by the United States which occupied 34\%.

There was a small decline in the significance of the United States in the worldwide hotel industry around 1980s'. Because of the changes of the worldwide economy, the effect of hotel rivals from the Pacific area has started to be engaged in the global hotel markets since the 1908s.

In the period of 1990s' the majority hotels, about 69,000, were established in south Asia, and a 50 percentage increase was reached in the Pacific Ocean. The "old" US corporations come back. In the United State and Canada real estate investment trusts (REIT) have a great influence on the expansion of the hotel industry.

They employed a significant novelty, the break up of the supervision and possession of the hotel, which had been conventionally associated. That insures much quicker return on investment The "J-REIT" law was performed in Australia. Among Europe countries, currently a growing number of mutual and retirement funds invest in the hotel industry. The United States is the leader in international hotel industry. The second country is Great Britain with eight large hotel chains. And the third one is Spain hosting five big hotel chains. Hotel cooperation and chain creation include either foreign ownership, which tends to be completely foreign and leads leakage of money, or joint ventures, franchising together with brand names and standards, management contracts, where hotels are managed but not owned by foreigners, consortia of independent hotels, involving common promotion, sales and local ownership. Hotel chain enterprises try to win with strategies including selling international, sourcing equipment and human resources, in particular managers, international and locating in a lot of different countries

The international hotel industry, by and large, had been growing more competitive as well as complex. For instance, ITT who are the owners of the Sheraton chains, have acquired the Italian Ciga operation, in competition with Marriott (US), who is also looking for considerable European expansion [4].

"Table I" best illustrates the process of the globalization in the hotel industry. Most independent hotels are local and so operate in quadrant 1 . Only a number of hotel chains, such as Hilton International, ACCOR and Holiday Inn, can be considered to compete on a truly global or geocentric basis and to operate in quadrant 4 . Due to the competition faced by the hotel industry, many independent hotels are trying to become affiliated with a global external network (quadrant 2) or to expand into a corporate chain (quadrant 3 ).

TABLE I. INTERNATIONAL HOTEL HOLDINGS

\begin{tabular}{|l|l|l|l|l|}
\hline \multicolumn{1}{|c|}{ Group } & \multicolumn{1}{|c|}{$\mathbf{1 9 7 8}$} & \multicolumn{1}{c|}{$\mathbf{1 9 8 9}$} & \multicolumn{1}{c|}{$\mathbf{1 9 9 7}$} & Growth\% \\
\hline Unites & Units & Units & Over Period \\
\hline Holiday Inn & 114 & 177 & 426 & 274 \\
\hline Hilton International & 72 & 102 & 160 & 122 \\
\hline Sheraton & 72 & 99 & 178 & 147 \\
\hline Hayatt & 26 & 63 & 76 & 192 \\
\hline Accor & 45 & 263 & 1277 & 2738 \\
\hline
\end{tabular}

There are two main factors in the central of internationalization of the hotel industry. The advances of information technology assist the international hotels to transfer information and data more quickly and easily. But, the expansion of large hotels is likely to cause monopoly. So the regulatory should be applied and changed to limit the further expansion which is greatly increased by the technology.

\section{THE INFLUENCE OF TECHNOLOGICAL AND} REGULATORY CHANGES ON THE INTERNATIONALIZATION OF HOTEL INDUSTRY

\section{A. Technology}

In the hospitality industry Information Technology is achieving appreciation as a method for delivering service consistency as well as setting up employee productivity. To sum up, with the introduction of more useful, capable and new information systems, it is clear that the innovations has been greatly influencing the way people do business in nearly every industry, including the hotel industry.

Technology which is one of the important strategic resources in hotel industry is the central player in internationalization. Developments in transportation technologies have greatly improved the capability of 
businesses to delivery their products and services beyond national boundaries and require increased capability in most areas of the industry within the past 20 years. The emerging systems grounded on information technologies such as global booking system are able to offer hotel organizations the opportunity to compete with their competitors as well as make up other travel industry providers' services in an international level. The development both in the national and international stage of the hotel industry is an outcome of technological progress. Offering value-added service is going to be more and more rely on the application of technology as a complement to human service in the hotel industry.

The development of complex information technologies enables the global exchange of information. The most important thing is that information technology will change the character of the rivalry itself. Due to the progress of the Global Distribution System, establishing transport and travel networks may offer significant opportunities for achieving competitive advantage by those hotel corporations with the necessary abilities and skills to use the new technology. In order to survive, hotel firms should respond to a rapidly shifting international marketplace and establish a international travel reservation system [4]. For human resource in the hotels industry, technology which facilitates on-line hotels and global booking systems will have an impact in terms of staff reductions on the front-desk hotel staff who used to perform those functions. This technology also calls for a different range of skills from employees. Training will therefore become a continuous need and the remaining jobs will require greater skills. [7]

\section{B. Regulation}

The international regulatory framework for the hotel industry is not heavy. Nation has been always playing the key role in mediating the relations between processes of international and territorial patterns of socioeconomic relationships in state spaces, so regulations in individual nations are very complicated for international hospitality executives. On condition that these firms are to be successful, their management must recognize tendencies and affairs in the political surroundings of each state they do business in, estimate their influence and timing, and reflect all of these in their tactical planning activities. Political factors are likely to greatly weaken the potential rate of international hotel development in a nation.

The scope of government regulation is different from country to country. And it is determined by the universal philosophy and politics of the government. The major characters of regulations influenced multinational hotel enterprises are as follows [4].

Because key areas of today's and future expansion aimed by main multinational hotel chains are the Asia-Pacific, South America as well as Europe, Kim and Olsen's research on the main events in the regulations that influence the development and operation of hotels held and run by multinational hotel chains in Asia is needed to bring forward here. They figure out that except for having the same regulations in the face of other multinational enterprises in the other industries, the hotel industry is dealt with some other fields of interventions as well. These involve minimum standards concerning the kind of hotel in order for it to receive a government rating, hours limiting the opening of restaurants in hotels, limitations on the type of events which could be held in hotels, needs concerning the use of local suppliers, the obstacles of large investors in hotels, laws affecting enforcement of management contracts, actions about overbooking and damages, and the relationship of taxation to tourism promotion.

\section{CONCLUSION}

It is incumbent on all hotel firms that have aspirations to develop brand names beyond national boundaries to understand what international means. A truly international enterprise will have the capacity to react quickly to market opportunities, no matter where they present themselves by applying business concepts that have been proven in the context of a global undertaking.

In conclusion, moving increasingly to internationalization, hotel corporations will need to well capitalize on technology, communicate much faster, run much more efficiently, provide their employees more opportunities and deliver their customers enhanced services. The international hotel industry should become accustomed the existing hotel production to changes in the requirements of the international and regional markets, align the existing and future hotel production with the rounded telecommunications and transportation networks, improve product and service quality with decreasing costs and establish the organizational ability to respond faster and more effectively throughout the distribution chain[4].

Those international enterprises that emphasize these issues at present will be better prepared for the international marketplace of tomorrow.

\section{ACKNOWLEDGMENT}

This paper is supported by Philosophy and Social Sciences Research Program of Heilongjiang Province: Research on the Model of the Feature of Business English "Triadic Reciprocal" Discipline (Grant No.: 16YYD11) and Philosophy and Social Sciences Research Program of Heilongjiang Province: Research on the Talent Cultivation Model of Business English from the Perspective of Ecologization (Grant No.: 15EDB01).

\section{REFERENCES}

[1] Alcouffe A., Coulomb F., 1993, Small and Medium-sized Business in European Tourist Sectors, OECD, Touluse, Paris.

[2] Cairncross F. The Death of Distance: How the Communications Revolution Will Change Our Lives. London: Orion Publishing; 1997.

[3] Dunning, H. and McQueen, M. 1982 Multinational Corporations in the International Hotel Industry. Annals of Tourism Research Vol.9, pp. 69-90.

[4] Go, M.F., and Pine, R.1995. Globalization Strategy in the Hotel Industry. London: Routledge. 
[5] Gomes, A. (1991). "Travel \& Tourism in the Global Village". Travel, Tourism and Hospitality Bulletin. Winter.

[6] Klančnik, V. R. 2003. Globalizacija turizma. EU - nova priložnost za slovenski turizem. Maribor: 6. slovenski turistični forum.

[7] Torrington, D. and Hall, L. (1991) Personnel Management a New Approach, New York: Prentice/Hall. 